\title{
O Consumidor
}

\author{
João Arruda
}

No meu modesto livrinho "Moloch Moderno", não me mostrei partidario da passagem do capital das mãos do particular para as do Estado. Pareceu-me sempre que a função do Estado é a de coibir os abusos do capital, praticados pelo capitalista movido exclusivamente pelo egoismo. Para isto, muito profunda reforma, julgo eu, é necessaria na organização do Estado Moderno: eis por que motivo me proclamo reformista. Enquanto porém o Estado é isto que conhecemos, minha maior confiança está na iniciativa particular pelo cooperatismo. A passagem do capital das mãos dos particulares para as do Estado, tem o inconveniente de contra este não haver nem mesmo o precarissimo recurso que hoje ha de certa repressão do egoismo do particular.

Vejo, ponto por ponto, sustentadas estas minhas idéias no fasciculo de Maio da notavel revista norte-americana "The Annals"

Estudando o que tem sido o consumidor (the ultimate consumer), pede que seja ele mais protegido do que o tem sido até hoje, notando que economistas e autoridades só cogitam dos interesses dos produtores e dos mediadores. Mostra o que tem sido nos Estados Unidos, graças aos esforços dos particulares, a informação aos consumidores, afim de que não despendam seu dinheiro senão proveitosamente: esclarecimento dado ao consumidor sobre os produtos que 
lhe são realmente de vantagem, e quais os em que ha muito ornato, muita coisa só para iludir os incautos e pouco observadores, sobre o tempo em que é mais vantajoso comprar tal ou tal artigo, etc. Sejam dados exemplos. Certos artigos vêm sobrecarregados de acessorios que de nenhum modo trazem aumento de gozo ao consumidor, como sejam diversos fantasticos melhoramentos em maquinas, que servem unicamente para inculcar uma suposta superioridade sobre o tipo anterior. Generos ha que tomam aspecto de utilidade que não têm, como reconhecem os tecnicos, e assim ha alimentos que os preconceitos populares fazem pagar o infeliz consumidor por preço muito mais elevado do que pagaria por generos muitissimo mais uteis. Um medicamento secreto, muitas vezes, não contem senão minima parte do que diz o prospecto haver consumido em drogas, e raramente tem a utilidade que proclama em seu pomposo reclamo.

Não me é possivel em um artigo destinado a uma revista destinada a assumptos juridicos e sociais vários, resumir tudo quanto encontro na importantissima colectanea, de mais de 200 paginas, da Academia Americana de Ciencias Politicas e Sociais (The Annals), e, por este motivo, entro no exame do que fez o Estado em prol do consumidor, do obscuro e anonimo cujo dinheiro deveria ser melhor aproveitado intervindo o Estado para o esclarecer em caso de desperdicio por ignorancia. Entre as mil acusações articuladas pelos ilustres cientistas norte-americanos, ha algumas que impressionam profundamente. Proibe o Estado o uso dos toxicos (narcoticos, anestesicos, etc.), mas de nenhum modo fiscaliza o comercio de medicamentos secretos onde encontram os viciados pasto para sua inclinação. Se veda serem aviadas fórmulas sem prescripçâo medica, por outra parte nenhuma cautela tem para que os consumidores não sejam vítimas dos negociantes de drogas secretas, suoedaneas das oficinais, preparadas por farmaceuticos de responsabilidade. Refere o mesmo fasciculo a que faço alusão, que, tendo o speaker de certa estação de radio comunicado ao publico que o departamento de saúde o 
prevenia de que a diminuição do uso da carne durante o verão era vantajosa para todos, veio o Secretario de Estado Mellon estabelecendo a censura dos avisos do broadcasting, afim de que não se trouxesse prejuizo aos negociantes de carne por uma mal entendida simpatia para com o consumidor: "offending a trade interest such as that of the packers, by any ill considered consumer sympathy"!

Parece que isto basta para justificar tudo quanto eu disse no "Moloch Moderno" sobre a ação atual do Estado, e mesmo mostrar que fui ainda muito pouco severo.

Manda a lealdade que se diga haver, no mesmo fasciculo a que estou fazendo referencia, um artigo de Frances Gannon, em que afirma ele muito ter feito o governo local de Nova York, a administração municipal, em beneficio dos habitantes da cidade. E' certo que é ele um dos funcionarios munipais e consequentemente algum tanto suspeito: todos sabemos que, pelo radio e pela imprensa oficial, é sempre proclamado o governo como sendo paternal e interessadissimo pelo bem estar do povo. Mesmo os chafarizes, tomados por elemento de propaganda em favor da bondade dos governantes, tinham e mantêm no Rio a inscrição de haverem sido doados pelo rei para bem de seu povo: o seu deveria vir com letra maiuscula por se referir a el rey nosso senhor. Mas, tornando ás providencias indicadas por Gannon, peço licença para apontar a de ser a dona de casa (housewife) informada em Nova York diariamente pelo radio, antes de partir para o mercado, dos preços dos principais artigos. Uma baixa ocasional em frutas, e até mesmo no preço dos espinafres é em tempo noticiado á consumidôra, o que è tão proveitoso ao consumidor quanto ao produtor, diz Gannon, habituado já a não atender senão ao interesse do produtor: "We could be of assistance to both consumer and the producer". Mas, prossegue, mostrando que certas peças de carne de muito menor preço podem ser acondicionadas na cozinha de modo a serem tão saborosas e nutritivas quanto as de mais alto custo, uma vez que a administração esclareça sobre isto a dona de casa (housewife). 
Não ha a menor dúvida sobre poder o governo fazer alguma coisa pelo consumidor, mas muita coisa ainda poderia fazer (uhat government does and might do for the consumer). Um excmplo tornado classico é o tirado da obra de Direito Administrativo de Orlando: um açougueiro não poderá melhorar as condições higienicas de seu estabelecimento, se o governo não obrigar o vizinho a fazer o mesmo sacrificio pecuniario em provcito dos freguezes. Se o governo nada faz neste sentido, impotente é o particular para conseguir qualquer progresso, salvo em cooperativas, em dadas hipoteses como passo a expôr.

E' precisamente o que aconselha a Academia de Ciencias Politicas e Sociais, cooperativas de iniciativa individual, quando ao individuo isolado faltam forças para o cometimento. E' tudo quanto ha de mais interessante o estudo que faz delas o notavel economista James Peter Warbasse, digno continuador da obra de Gide. Prova que as cooperativas de consumo são o unico refugio da classe pobre, á quàl não só o Estado nenhuma proteção dá, mas mesmo prejudica, favorecendo a classe dos ricos produtores. Refere que as sociedades cooperativas de consumo se têm estendido por todo o mundo. Entre os fatos extraordinarios, menciona que, na Suissa, ha mais de 200 sociedades cooperativas de telefones, operando tão modesta e economicamente que chegam ao ponto de lançar mão dos arames de cercas para transmissão eletrica! Estenderam-se as cooperativas por todo o mundo: Suecia, Dinamarca, Islandia, Alemanha, Italia, Austria e Russia, embora nestes ultimos paises tenham sof rido a guerra dos governos. Elas se ocupam com os mais variados artigos de consumo: roupa, habitação, generos alimenticios, comunicações telefonicas, assistencia a doentes por medicos e enfermeiros, hospitais, funerais e tudo quanto pode significar consumo, notadamente consumo pelas classes menos protegidas da fortuna. Até de materia prima para pequenas industrias se ocupam as cooperativas. Muito poderia o governo fazer pelo pobre consumidor (might do for the consumer), pelo dinheirinho da classe infima da socie- 
dade quanto ao aspecto economico (consumer's dollar), mas, como afirma um dos cientistas norte-americanos, só se têm movido alguns deles para guerrear as cooperativas, segundo diz a Academia Americana.

No "Moloch Moderno" foi justamente o recurso ás cooperativas que eu aconselhei aos fracos contra os opressores, não como sendo solução radical do problema economico, mas sim como constituindo um paliativo, o unico de mim conhecido.

Enfim o mundo se move, os pequenos buscam seus interesses, e fazem o que podem para não terem necessidade do auxilio dos grandes da terra, os quais só se interessam pelos seus pares.

Não seria caso de dedicarem os estudantes do doutorado sua atenção ao estudo da fórma de organização das cooperativas no Brasil? Não será digno de imitação o que por elas tcm feito o mundo culto? 